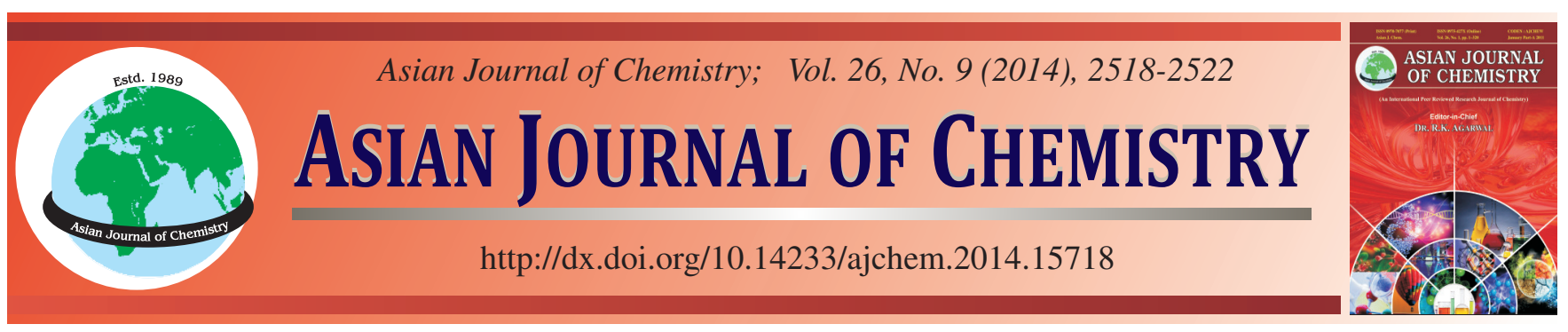

\title{
Some Physical and Chemical Characteristics, Molecular Typing of Isolated E. coli Strains of Fountain Waters, Turkey
}

\author{
Pinar Sekerci, Mustafa Gurses* and Bulent Cetin
}

Department of Food Engineering, Faculty of Agriculture, Atatürk University, 25240 Erzurum, Turkey

*Corresponding author: Fax: +90 442 3150689; Tel: +90 442 2312488; E-mail: mgurses@ atauni.edu.tr

In this study, water samples collected from public fountains in Erzurum city centrum were analyzed and their drinking quality was evaluated. A total of 45 water samples were subjected to microbiological, chemical and physical analyses. Microbiological analysis results showed that total and fecal coliform bacteria were found in 10 samples (22.7\%) and Clostridium perfringens in only one sample. In addition, Escherichia coli were isolated from these 10 samples. RAPD-PCR technique was used for confirming phylogenetic diversity among $E$. coli species isolated from various fountains. Six of 45 typical $E$. coli isolates were determined to be different strains. Average colour, water temperature, turbidity, electrical conductivity, $\mathrm{pH}$, dissolved oxygen, chloride, nitrite, nitrate, sulphate, phosphate, sodium, ammonium, potassium, magnesium, calcium, iron and manganese values of the samples were determined as $1.04 \mathrm{mg} \mathrm{Pt} \mathrm{L}^{-1}, 21.43^{\circ} \mathrm{C}, 0.14$ NTU, $456.80 \mu \mathrm{S} \mathrm{cm}^{-1}, 7.26,5.36,3029,0.12,2.09,50.48,22.71,35.91,0.32,14.99,31.20,105.00,0.16$ and $2.64 \mathrm{mg} \mathrm{L}^{-1}$, respectively.

Keywords: Fountain water, $E$. coli, Coliform bacteria, RAPD-PCR.

\section{INTRODUCTION}

Being an indispensable source for the existence and maintenance of life and a source which is in constant circulation in the nature, water can be contaminated with some physical, chemical and microbiological agents until it is delivered to the consumption point ${ }^{1-3}$. For this reason, provision of consumers with a quality and safe drinking water is very important for public health. The quality of water provided for the consumers, to a large extent, depends on the quality of water source, showing the necessary sensitivity to every stage from water's treatment to its distribution and the provision of appropriate water quality by taking drinking water standards into consideration ${ }^{4}$.

Exposure of waters, which are to be used as drinking water, to contamination because of various reasons affects public health as much as it affects potability of the water ${ }^{5,6}$. As a matter of fact, various disease causes (Salmonella typhimurium, E. coli, Aeromonas hydrophyla, C. perfringens and Shigella) can be transmitted to humans through unhygienic waters ${ }^{7}$. According to World Health Organization $80 \%$ of diseases in developing countries are reported to result from drinking water ${ }^{8}$.

The best way to determine water's consumability quality in terms of health is to investigate the existence of micro- organisms which indicate the existence of enteric bacteria in the water. The bacteria indicating that water is contaminated with feces are coliform bacteria such as $E$. coli which are members of Enterobacteriaceae family, which can reproduce at $44.5^{\circ} \mathrm{C}$ and are able to ferment lactose by forming acid and gas, indol (+) and tolerant of temperature and such as Escherichia, Citrobacter, Enterobacter, Klebsiella which are able to ferment lactose at $37^{\circ} \mathrm{C}^{9}$. Coliform bacteria are accepted as an appropriate microbial indicator in determining water quality for coliform bacteria can be easily detected and counted in water ${ }^{10,11}$. Drinking water with enteric bacteria also causes transmission of these bacteria among individuals ${ }^{12-15}$.

Many analysis methods have been developed for microbiological control of waters. However, devices and methods utilized for this purpose are different for almost each microorganism and the existing analysis methods yield results in a long period of time for they are generally for cultivating microorganisms in the culture medium. It was discovered that drinking water can include many other microorganisms in addition to microorganisms which are called as indicator microorganisms and considered to reveal water's microbiological quality. All these facts revealed the need for safe and rapid analysis methods ${ }^{16}$. For this reason, polymerase chain reaction (PCR), which is a rapid method, is widely used today $^{17}$. 
In this study, it was aimed to determine the usage and drinking quality of drinking water samples collected from some of the most frequently used public fountains in Erzurum city centrum through physical, chemical and microbiological analyses and to carry out the molecular typing of isolated E. coli strains by using RAPD-PCR method.

\section{EXPERIMENTAL}

Water samples: Two samples were taken from each one of the selected fountains for the study. These samples were put in sterile sample vessels, taken right away to the Microbiology Laboratory of the Department of Food Engineering in Atatürk University and kept at $+4{ }^{\circ} \mathrm{C}$ until the analysis.

Physical and chemical analyses: $\mathrm{pH}$ values of waters were detected at $25 \pm 3{ }^{\circ} \mathrm{C}$ using a laboratory-type $\mathrm{pH}$ meter (Hanna $211 \mathrm{pH}-M e t e r^{18}$. Turbidity measurement was realized by using a HF Mikro1000 (HF Scientific, USA) brand turbidimeter in accordance with the method expressed in Anonymous ${ }^{19}$ and colour measurement was realized by using a DR 5000 spectrophotometer device (Hach, USA) ${ }^{20}$. A laboratory-type conductivity measurement device (Crison, Spain) was used to measure electrical conductivity ${ }^{21}$. Photoflex (WTW 82362n Weilheim, Serial Number 06440414, Germany) device was used in hardness analysis and an oxygen meter device (Thermo Scientific Orion Star, Singapore) was used to detect the amount of dissolved oxygen ${ }^{22}$.

The amounts of free chlorine were detected by using Spectroquant (Merck) ready kits ${ }^{22}$; the amounts of nitrite, nitrate and ammonium were detected by using Dionex 3000 Ion Chromatography device ${ }^{23}$; the detection of other minerals, however, was realized by using a Thermo ICP-OES (Thermo Scientific, USA) device in accordance with the method given by Jenniss et al. ${ }^{24}$ and Rubinson and Rubinson ${ }^{25}$.

Microbiological analyses: Hydrophobic grid membrane filtration (HGMF) technique was used in the enumeration of total and fecal coliforms ${ }^{26}$. m-FC and m-ENDO media were used for isolation of fecal and total coliform. Filters were left to incubation on m-FC (Merck) at $44.5^{\circ} \mathrm{C}$ for $24 \mathrm{~h}$ and mENDO (Merck) media at $37{ }^{\circ} \mathrm{C}$ for $24 \mathrm{~h}$. At the end of incubation, enumerations were realized in these media ${ }^{27}$. Clostridium perfringens samples were directly added egg yolk after they were infiltrated and their cultivation was carried out on TSC (Tryptose Sulphite Cycloserine) (Merck) medium. After this medium became solid, a second layer (that does not contain egg yolk emulsion) of nearly $10 \mathrm{~mL}$ of the same medium was placed onto the cultivated petri plates and it was incubated under anaerobic conditions at $37^{\circ} \mathrm{C}$ for a period of $24 \mathrm{~h}$. At the end of the incubation, black colonies with a diameter of 2-4 mm, around which is an opaque zone depending on lecithinase activity, were enumerated as C. perfringens ${ }^{28,29}$. For the detection of $E$. coli strains, colonies showing positive feature on $\mathrm{m}-\mathrm{FC}$ and $\mathrm{m}-\mathrm{ENDO}$ media were taken and they were cultivated on EMB (Merck) culture medium for confirmation of isolates. EMB agar plates were incubated at $37{ }^{\circ} \mathrm{C}$ for a period of $48 \mathrm{~h}$ and metalic green colonies were evaluated as being suspicious $E$. coli. DNA isolation was carried out from the suspicious $E$. coli strains in accordance with the method expressed by Günal ${ }^{30}$. Amplification process was realized in a Thermo-Cycler (USA) device in accompany with $(\mathrm{GTG})_{5}$ primer with RAPD-PCR Method ${ }^{22}$. Amplified PCR samples were submerged in agarose gel electrophoresis at $70 \mathrm{~V}$ for a period of $1-1,5 \mathrm{~h}$ and outcomes were obtained with a UV Transilluminator Screening device (Ultralum, USA) ${ }^{22}$. Genetic analysis was confirmed by using an E. coli GM 1402 strain. The strain obtained from Department of Food Engineering, Atatürk University, Erzurum, Turkey.

Statistical analysis: SPSS for Windows (Release 12.0) was used to statistically analyze the data obtained in the study, average values and their standard deviations were determined.

\section{RESULTS AND DISCUSSION}

Physical and chemical analyses: In the Table- 1 are given the lowest, the highest and average colour, temperature, electrical conductivity and turbidity values of water samples which collected from some of the most frequently used public fountains from which Erzurum Metropolitan Municipality Water and Sewerage Administration collects samples in certain periods for control and analysis. As it is seen in the Table-1, the lowest, the highest and average colour, turbidity, electrical conductivity and temperature values of samples were determined as 0.12, 3.45, $1.04 \mathrm{mg} \mathrm{Pt} \mathrm{L}^{-1} ; 0.02,0.45,0.14 \mathrm{NTU} ; 141$, 847 and $456.80 \mu \mathrm{S} \mathrm{cm}^{-1} ; 17,23$ and $21.43^{\circ} \mathrm{C}$, respectively.

TABLE-1

COLOUR, TURBIDITY, ELECTRICAL CONDUCTIVITY AND TEMPERATURE VALUES OF FOUNTAIN WATERS

\begin{tabular}{lcccc}
\hline Parameters & $\mathrm{N}$ & Lowest & Highest & Average \\
\hline Colour $\left(\mathrm{mg} \mathrm{Pt} \mathrm{L}^{-1}\right)$ & 45 & 0.12 & 3.45 & $1.04 \pm 0.76$ \\
Turbidity $(\mathrm{NTU})$ & 45 & 0.02 & 0.45 & $0.14 \pm 0.10$ \\
$\begin{array}{l}\text { Electrical conductivity } \\
\left(\mu \mathrm{S} \mathrm{cm}^{-1}\right)\end{array}$ & 45 & 141.00 & 847.00 & $456.80 \pm 202.51$ \\
Temperature $\left({ }^{\circ} \mathrm{C}\right)$ & 45 & 17.00 & 23.00 & $21.43 \pm 1.83$ \\
\hline
\end{tabular}

These values were found to be higher than the values given in Regulation concerning Water Intended for Human Consumption given in TS $266^{31}$. Agaoglu et al. ${ }^{5}$ collected 30 water samples from 15 different sources in Van province and its vicinity and detected that only spring waters were completely colourless, odorless, clear and in normal taste. Günsen et al. ${ }^{1}$ detected in his study where he examined water quality of 28 different spring water in Bursa Uludag that the samples taken from the outlet point comply with "Alimentary Products Law" in terms of colour, turbidity, odor and sediment. Abali et al. ${ }^{32}$ collected water samples from 16 different points of Kula and Gökçeören's vicinity and detected that turbidity values of samples change between 0.20-0.37 NTU and electrical conductivity values of samples change between 396.00-699.00 $\mu \mathrm{S} \mathrm{cm} \mathrm{cm}^{-1}$.

The $\mathrm{pH}$, dissolved oxygen, chloride, nitrite, nitrate, sulphate, phosphate, sodium, ammonium, potassium, magnesium, calcium, iron and manganese values of water samples are summarized in Table-2. $\mathrm{pH}$ values of water samples were detected to change between 6.80-7.73 with an average of $7.26 \mathrm{mg} \mathrm{L}^{-1}$; dissolved oxygen amounts to change between 4.80-6.30 with an average of $5.36 \mathrm{mg} \mathrm{L}^{-1}$; chloride amounts to change between 16.22 58.17 with an average of $30.29 \mathrm{mg} \mathrm{L}^{-1}$; nitrite amounts to change between $0.00-0.35$ with an average of $0.12 \mathrm{mg} \mathrm{L}^{-1}$; 


\begin{tabular}{|c|c|c|c|c|}
\hline \multicolumn{5}{|c|}{$\begin{array}{l}\text { TABLE-2 } \\
\text { pH, DISSOLVED OXYGEN AND SOME IMPORTANT } \\
\text { MINERAL LEVELS OF FOUNTAIN WATERS }\end{array}$} \\
\hline Parameters & $\mathrm{N}$ & Lowest & Highest & Average \\
\hline $\mathrm{pH}$ & 45 & 6.80 & 7.73 & $7.26 \pm 0.175$ \\
\hline Dissol. oxygen $\left(\mathrm{mg} \mathrm{L}^{-1}\right)$ & 45 & 4.80 & 6.30 & $5.36 \pm 0.313$ \\
\hline Chloride $\left(\mathrm{mg} \mathrm{L}^{-1}\right)$ & 45 & 16.22 & 58.17 & $30.29 \pm 10.167$ \\
\hline Nitrite $\left(\mathrm{mg} \mathrm{L}^{-1}\right)$ & 45 & 0.00 & 0.35 & $0.12 \pm 0.163$ \\
\hline Nitrate $\left(\mathrm{mg} \mathrm{L}^{-1}\right)$ & 45 & 0.43 & 5.91 & $2.09 \pm 0.941$ \\
\hline Sulphate $\left(\mathrm{mg} \mathrm{L}^{-1}\right)$ & 45 & 24.66 & 72.20 & $50.48 \pm 9.953$ \\
\hline Phosphate $\left(\mathrm{mg} \mathrm{L}^{-1}\right)$ & 45 & 13.75 & 27.38 & $22.71 \pm 3.019$ \\
\hline Sodium $\left(\mathrm{mg} \mathrm{L}^{-1}\right)$ & 45 & 21.38 & 63.78 & $35.91 \pm 9.450$ \\
\hline Ammonium $\left(\mathrm{mg} \mathrm{L}^{-1}\right)$ & 45 & 0.01 & 0.91 & $0.32 \pm 0.186$ \\
\hline Potassium (mg L $\left.{ }^{-1}\right)$ & 45 & 3.76 & 40.86 & $14.99 \pm 7.619$ \\
\hline Magnesium $\left(\mathrm{mg} \mathrm{L}^{-1}\right)$ & 45 & 7.22 & 48.91 & $31.12 \pm 8.436$ \\
\hline Calcium $\left(\mathrm{mg} \mathrm{L}^{-1}\right)$ & 45 & 29.66 & 158.57 & $105.00 \pm 27.874$ \\
\hline Iron $\left(\mathrm{mg} \mathrm{L}^{-1}\right)$ & 45 & 0.00 & 2.42 & $0.16 \pm 0.479$ \\
\hline Manganese $\left(\mathrm{mg} \mathrm{L}^{-1}\right)$ & 45 & 1.10 & 6.80 & $2.64 \pm 0.929$ \\
\hline
\end{tabular}

nitrate amounts to change between 0.43-5.91 with an average of $2.09 \mathrm{mg} \mathrm{L}^{-1}$; sulphate amounts to change between 24,6672,20 with an average of $50.48 \mathrm{mg} \mathrm{L}^{-1}$; phosphate amounts to change between 13.75-27.38 with an average of $22.71 \mathrm{mg} \mathrm{L}^{-1}$; sodium amounts to change between 21.38-63.78 with an average of $35.91 \mathrm{mg} \mathrm{L}^{-1}$; ammonium amounts to change between 0.01-0.91 with an average of $0.32 \mathrm{mg} \mathrm{L}^{-1}$; potassium amounts to change between 3.76-40.86 with an average of $14.99 \mathrm{mg} \mathrm{L}^{-1}$; magnesium amounts to change between 7.22-48.91 with an average of $31.12 \mathrm{mg} \mathrm{L}^{-1}$; calcium amounts to change between 29.66-158.57 with an average of $105.00 \mathrm{mg} \mathrm{L}^{-1}$; iron amounts to change between $0.00-2.42$ with an average of $0.16 \mathrm{mg} \mathrm{L}^{-1}$ and manganese amounts to change between 1.10-6.80 with an average of $2.64 \mathrm{mg} \mathrm{L}^{-1}$.

It was detected that $\mathrm{pH}$ values and dissolved oxygen amounts of water samples comply with the values and amounts given in Regulation concerning Water Intended for Human Consumption. Dönderici et al. ${ }^{32}$ found out that $\mathrm{pH}$ value of spring waters to be between 6.71 and $8.21 . \mathrm{pH}$ values of spring waters were detected to be 6.95-8.16 in Van province and its vicinity $^{5}$; 6.8-7.4 in spring waters of Bursa Uludag ${ }^{1}$; 6.5-8.2 in Bursa Metropolitan Municipality spring waters ${ }^{33}$ and 7.78.0 in Harbiye spring waters ${ }^{34}$. Alemdar et al. ${ }^{33}$ collected 164 storage water and municipial water samples from Bitlis city centrum and its districts and detected $\mathrm{pH}$ values of these water samples to be at the level of 7.41 averagely. These results are parallel with our results. Abali et al. ${ }^{31}$ reported $\mathrm{pH}$ values to change between 7.3 and 7.7 in a similar study.

As it is clearly seen in the Table-2, nitrite amounts of fountain waters were detected to be between $0.00-0.35 \mathrm{mg} \mathrm{L}^{-1}$, nitrate amounts to be between $0.43-5.91 \mathrm{mg} \mathrm{L}^{-1}$, chloride amounts to be between $16.22-58.17 \mathrm{mg} \mathrm{L}^{-1}$, sulphate amounts to be between $24.66-72.20 \mathrm{mg} \mathrm{L}^{-1}$ and sodium amounts to be between $21.38-63.78 \mathrm{mg} \mathrm{L}^{-1}$. These values were detected to comply with surface waters parametric values given by the Ministry of Health and Turkish Standards Institution (TS 266). Günsen et al. ${ }^{1}$ detected nitrite in $7.03 \%$ of municipial and drinking water samples in the study carried out in Bursa. Abali et al. ${ }^{31}$ detected nitrite, nitrate, chloride and sulphate values of water samples that they examined in Kula and Gökçeören to be at the levels of 0.003-0.00, 3.05-9.32, 21.5-4.70 and 14.70$39.00 \mathrm{mg} \mathrm{L}^{-1}$, respectively.
Phosphate, ammonium, potassium and magnesium values of water samples were detected to be between 13.75-27.38, $0.01-0.91,3.76-40.86$ and $7.22-48.91 \mathrm{mg} \mathrm{L}^{-1}$, respectively. These figures were determined to be higher than the figures given in Regulation concerning Water Intended for Human Consumption.

Alemdar et al. ${ }^{33}$ collected water samples from Bitlis province and its districts and detected magnesium values in these samples to be lower $\left(3.81 \mathrm{mg} \mathrm{L}^{-1}\right)$ than drinking water samples of Güroymak district. Abali et al. ${ }^{31}$, however, detected magnesium values in water samples to be between 10.1-92.94 mg $\mathrm{L}^{-1}$.

Calcium, iron and manganese values of samples showed change between 29.66-158.57, 0.00-2.42 and 1.10-6.80 mg $\mathrm{L}^{-1}$, respectively. These figures are parallel with the surface waters parametric values of the Ministry of Health and Turkish Standards Institution. Abali et al. ${ }^{31}$, however, detected calcium, iron and manganese values of samples to be between 161.9283.4, 0.00-0.01 and 10.1-92.94 $\mathrm{mg} \mathrm{L}^{-1}$, respectively. Dönderici et al..$^{32}$ detected iron values to be lower than the limiting value ( $1 \mathrm{mg} \mathrm{L}^{-1}$ ) in 16 water samples and iron values to change between 2.40-86.64 $\mathrm{mg} \mathrm{L}^{-1}$ in 14 water samples and reported these figures to be in compliance with the regulation. The research values that we obtained show similarity with the research results of Günsen et al. ${ }^{1}$, Agaoglu et al. ${ }^{5}$ and Abali et al. ${ }^{31}$.

Microbiological analysis results: In Table-3 are given the lowest, the highest and average (per each/100 mL) numbers of total coliform, fecal coliform and C. perfringens belonging to analyzed 45 fountain waters.

TABLE-3

THE NUMBERS OF TOTAL COLIFORM, FECAL COLIFORM AND C. PERFRINGENS OF WATER SAMPLES

$\begin{array}{llll}\text { Parameters } & \mathrm{N} & \text { Lowest Highest Average }\end{array}$

$\begin{array}{lllll}\text { Total coliform } & 45 & 0.00 & 98.00 & 6.87 \pm 18.918\end{array}$

$\begin{array}{lllll}\text { Fecal coliform } & 45 & 0.00 & 41.00 & 3.69 \pm 8.878\end{array}$

$\begin{array}{lllll}\text { C. perfringens } & 45 & 0.00 & 5.00 & 0.11 \pm 0.745\end{array}$

As a result of microbiological analyses, the total numbers of total coliform, fecal coliform and C. perfringens in 45 samples were detected to be $10(22.7 \%), 10(22.7 \%)$ and 1 $(2.3 \%)$, respectively. Alemdar et al. ${ }^{33}$ detected the positiveness rate of coliform bacteria in 164 samples collected from storage and municipal waters in Bitlis province and its districts to be $12 \%$ (19/164). Günsen et al. ${ }^{1}$ detected coliform bacteria in 7 samples out of 100 drinking and municipal water samples. Kirecci et al. ${ }^{3}$ examined 1469 water samples taken from water used by military troops in Kars and Sarikamis with membrane filtration. Kirecci et al. ${ }^{3}$ isolated $E$. coli from 439 (30\%) of all samples and could not detected $E$. coli in the rest of the samples. Avci et $_{\text {al }}{ }^{34}$, detected temperature tolerant $E$. coli (fecal coliform) in $119(34.7 \%)$ and total coliform in $223(65.3 \%)$ of a total of 2495 drinking water samples as pathogen factors in the study carried out in Tokat province city centrum.

In our study, fecal contamination was detected in 15 of total 45 fountains and 45 E. coli strains were isolated from 15 contaminated fountains. E. coli isolates of 15 suspicious strains out of total 45 isolates was realized by cultivating them on 
EMB culture medium from agar media whose fecal coliform enumeration were performed. Typical metalic bright green colonies developing on EMB agar were subjected to IMVIC test and 45 E. coli strains were isolated. RAPD-PCR technique was used for molecular $E$. coli typing. As a result of the analyses, the 45 isolates could be divided into six different fingerprint groups according to their different polymorphic bands. The band length of these separated 6 genotypes was detected to be between 750-1000 base pair. In order to reveal the validity of the genotyping method used, the same bands were obtained as a result of amplifications made with the same strains at different times (Fig. 1).

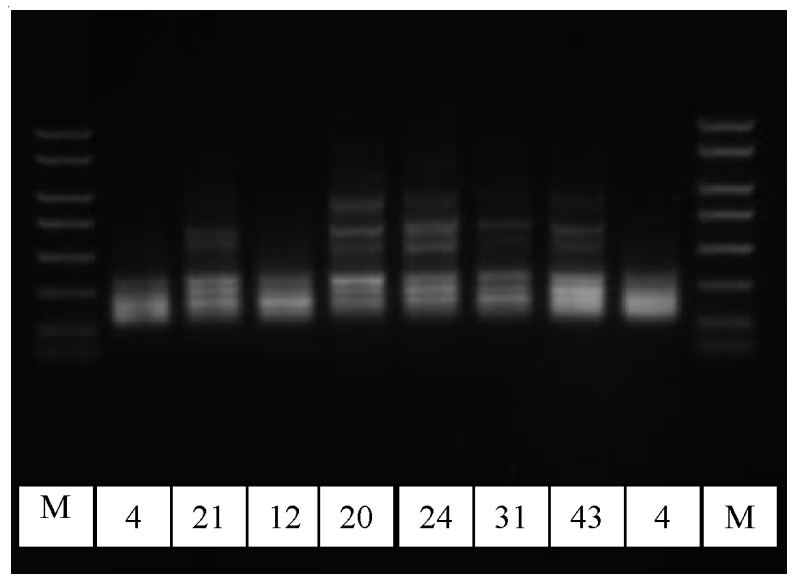

Fig. 1. DNA agarose gel electrophoresis image belonging to rapd-pcr results of fountain water samples

In Fig. 1 is given the agarose gel image of DNA bands obtained as a result of RAPD-PCR analysis of 6 different E. coli strains isolated from 45 fountain water samples. Figures on the image are fountain numbers, $\mathrm{K}$ is (control = No 4) and $\mathrm{M}$ is marker.

Balkay ${ }^{35}$ detected Salmonella, Shigella and E. coli in Kars stream using Multiplex PCR method and detected E. coli especially in May and June, Balkay ${ }^{35}$ detected E. coli only in samples collected from the outer borders of the city in July and August and could not detect this type of bacteria in September. Balkay ${ }^{35}$ submerged the PCR amplifications of these bacteria into DNA agorose gel electrophoresis and determined band lengths of E. coli, Salmonella and Shigella strains as 147 base pair 526 base pair and 408 base pair, respectively. Hadise et al. ${ }^{16}$ carried out the microbiological analysis of well water belonging to military troops in Ankara Garnison and detected E. coli in 14 water samples out of 28 water samples. Researchers using Quadro Multiplex PCR method detected band lengths of thermotolerant coliforms, E. coli, Salmonella and Shigella strains to be 326 base pair, 147 base pair, 526 base pair and 408 base pair, respectively. It is seen that band length values of $E$. coli strains isolated by these researchers are lower than the band length values of 6 E. coli strains that we examined. Using Taq Man PCR method, Frahm and $\mathrm{Obst}^{36}$ detected Enterococcus in $96 \%$ of 55 water samples while they detected E. coli in $98 \%$ of these 55 water samples. FodeVaughan et $a l .{ }^{37}$ using PCR (DPCR) method and Tims and Lim $^{38}$ using Direct and Real-time PCR method detected $E$. coli $\mathrm{O} 157: \mathrm{H} 7$ in water and food samples from the market.
Similarly, Sirilak et al. ${ }^{39}$ and Maheux ${ }^{40}$ detected the existence of E. coli in water samples using PCR method in their studies.

\section{Conclusion}

In terms of the parameters examined in this study, physical and chemical analysis results of water samples collected from the selected public fountains in Erzurum city centrum reveal that these waters are in compliance with the standards and do not show any negative quality. However, the detection of $E$. coli in some of these fountains shows that these waters were subjected to an external fecal contamination. 6 of all typical $E$. coli strains isolated from these fountains were detected to be different in molecular DNA structure. It is concluded that because of the potential health risk, it is necessary not to utilize waters of these fountains where fecal contamination was detected and it is necessary to warn consumers about this matter.

\section{ACKNOWLEDGEMENTS}

The authors are grateful to the Scientific Research Project Department of Atatürk University (BAP) for supporting this research Project.

\section{REFERENCES}

1. U. Gunsen, S. Anar and H. Gündüz, S.D. Ü Fakültesi Dergisi, 7, 31 (2000).

2. S. Aysal, Biyoloji Anabilim Dali, Isparta, Turkey (2004).

3. E. Kirecci, M. Savasci and H. Uslu, Atatürk Üniv. Vet. Bil. Derg., 1, 29 (2006).

4. S. Akturk, Çukurova Üniversitesi Fen Bilimleri Enstitüsü Yüksek Lisans Tezi, Adana, Turkey (2009).

5. S. Agaoglu, K. Ekici, S. Alemdar and S. Dede, Y.Y. Üniv. Tip Fak. Derg, 6, 30 (1999).

6. H. Gülboy and S.D.Ü. Fen, Bilimleri Enstitüsü Yüksek Lisans Tezi, Isparta, Turkey (2004).

7. R.Y. Cartwright, Appl. Microbiol., 94, 12 (2003).

8. N. Balkaya and A. Açikgöz, Standart Dergisi, 29 (2004).

9. WHO, Guidelines For Drinking Water Quality, Austria, edn. 2, pp. 10-92 (1996).

10. K. Töreci, Klinik Mikrobiyoloji, Istanbul, Turkey (1992).

11. S. Tofan, Selçuk Üniv. Müh. Fak. Kimya A.B.D. Yüksek Lisans Tezi, Konya, Turkey (2008).

12. S. Demirtas, Cumhuriyet Ünv. Tip Fak. Mikrobiyoloji Anabilim Dali Uzmanlik Bitirme Tezi, Sivas, Turkey (1997).

13. S.C. Edberg, E.W. Rice, R.J. Karlin and M.J. Allen, J. Appl. Microbiol., 88, 106S (2000).

14. Ö. Kisa, Ulusal Sindirim Yolu Ile Bulapan Enfeksiyonlar Sempozyumu, pp. 164-168 (2005).

15. A. Özaslan, Çukurova Üniversitesi Fen Bilimleri Enstitüsü, Yüksek Lisans Tezi, Adana, Turkey (2009).

16. M. Hadise, R. Ugur and Ö.F. Tekbas, Gülhane Tip Dergisi, 44, 373 (2002).

17. A.A. Atalay, Erciyes Üniversitesi Tip Fakültesi Mikrobiyoloji ve Klinik Mikrobiyoloji Ana Bilim Dali, Tip Uzmanlik Tezi, Kayseri, Turkey (2006).

18. T.S. Anonim, 3263 ISO 10523/Nisan, Necatibey Cad., Bakanliklar, Ankara, Turkey (1999).

19. Anonymous, Standard Methods for the Examination of Water and Wastewater 2130b (1999).

20. 6392 EN ISO 7887/Nisan. Necatibey Cad., Bakanliklar, Ankara, Turkey (1998).

21. Anonymous, Standard Methods for the Examination of Water and Wastewater, 2510 (2005).

22. Ö. Koçak, Selçuk Üniversitesi Saglik Bilimleri Enstitüsü Besin Hijyeni ve Teknolojisi Anabilim Dali, Yüksek Lisans Tezi, Konya, Turkey (2007).

23. A. Yildiz, Ö. Genç and S. Bektas Enstrümental Analiz Yöntemleri, Hacettepe Üniversitesi Yayinlari A-64, Ankara, Turkey (1993). 
24. S.W. Jenniss, S.A. Katz and R.W. Lynch, Applications of Atomic Spectrometry to Regulatory Compliance Monitoring, Wiley-VCH, Inc., edn. 2 (1997).

25. K.A. Rubinson. and J.F. Rubinson, Contemporary Instrumental Analysis, Prentice-Hall (2000).

26. A.O.A.C. Anonymous, Total Coliforms, Fecal Coliforms and Escherichia coli in Foods: Hydrophobic Grid Membrane Filter Method. Sec. 17.3.08, Method 983.25, In Official Methods of Analysis of AOAC International, 16th Ed., P.A. Cunniff (Ed.). 18-20. AOAC, International, Gaithersburg, Md. (1995).

27. A.H.W. Hauschild and R. Hilsheimar, Appl. Microbiol., 27, 78 (1974).

28. A.H.W. Hauschild and R. Hilsheimar, Appl. Microbiol., 27, 521 (1974).

29. S. Günal, Inönü Üniversitesi Saglik Bilimleri Enstitüsü Müdürlügü, Yüksek Lisans Tezi, Malatya, Turkey (1997).

30. Anonim, TS266, Resmi Gazete, Ankara, Turkey (2005).
31. Y. Abali, Targan, Ü. Süner and C. Süner, CBÜ Soma Meslek Yüksekokulu Teknik Bilimler Dergisi, 2, 10 (2008).

32. Z.S. Dönderici, Turk Hij. Deney. Biyol. Derg., 67, 167 (2010).

33. S. Alemdar, T. Kahraman, S. Agaoglu and M. Alisarli, Ekoloji Cevre Dergisi, 19, 29 (2009).

34. S. Avci, M.Z. Bakici and M. Erandaç, Cumhuriyet Üniv. Tip Fak. Dergisi, 28, 107 (2006).

35. F. Balkay, Kafkas Üniversitesi Fen Bilimleri Enstitüsü Kimya Anabilim Dali, Yüksek Lisans Tezi, Kars, Turkey (2008).

36. E. Frahm and U. Obst, J. Microbiol. Methods, 52, 123 (2003).

37. K.A. Fode-Vaughan, J.S. Maki, J.A. Benson and M.L.P. Collins, Lett. Appl. Microbiol., 37, 239 (2003).

38. T.B. Tims and D.V. Lim, J. Microbiol. Methods, 55, 141 (2003),

39. S. Sirilak, R. Pongruj, H. Zulhainan, V.S. Oleg and C.P. Porntip, Southeast Asian J. Trop. Med. Public Health, 39, 6 (2008).

40. A.F. Maheux, F.J. Picard, M. Boissinot, L. Bissonnette, S. Paradis and M.G. Bergeron, Water Res., 43, 3019 (2009). 